\title{
The Growth Accounting for Industry and Services of Slovakia and Czechia
}

\author{
Manuela RAISOVÁ \\ Technical University of Košice, Košice, Slovakia \\ manuela.raisova@tuke.sk
}

\begin{abstract}
The last economic crisis has brought many questions and few answers. The crisis has shown how economies are internally vulnerable to external factors. Internal vulnerability is also attributed to the use of available resources in the economy. The aim of the article was to find out how the individual factors of industry and services contribute to total production and economic growth. We used the method of growth accounting: a dual approach that allowed us to track the contribution of individual inputs to production and economic growth. We wanted to prove that if one factor had at least a $5 \%$ greater share of overall growth than other factors for the whole economy, then this factor would be the main one for the individual sectors of the economy as well. Verification was carried out for two countries - Slovakia and Czechia in the crisis and the post-crisis period (2008-2016). We note that there was only one country whose main factor of economic growth was identical in both sectors (industry and services) and for the economy as a whole. It was Czechia and the factor was TFP.
\end{abstract}

Keywords: Growth Accounting, TFP, Capital.

\section{$1 \quad$ Introduction}

After the second wave of the economic crisis, the economies began to gradually recover from the consequences of a rapid but very intense crisis. Countries with the pre-crisis economic growth tried to return the economy to previous performance as quickly as possible. However, the crisis has highlighted a number of facts that need to be taken into account when designing an economic policy. Thanks to the implementation of modern technologies, the speed of process execution has increased. The economy must respond promptly also in areas where it is very difficult. This speed puts pressure on governments to devote more attention to the essence of their economic growth they want to achieve.

Our goal was to investigate if there is any the difference in main factors involved in production of overall economy and of the individual sectors. We used the methods of growth accounting: dual approach. We wanted to prove that if one factor had at least a 5\% greater share of overall growth than other factors for the whole economy, then this factor would be the main one for the individual sectors of the economy as 
well. In the previous analysis we found that in the Czech case the TFP was such an important factor (for the economy as a whole) throughout the monitored period. In the case of Slovakia, it was capital before the crisis and TFP was during and after the crisis. We wanted to find out if the same factors were decisive for industry and services. We followed development in two countries - The Czech Republic and Slovakia in the period $2008-2016$.

In the second part we have compiled a brief overview of the literature from the field of our problems. In the third part we briefly describe the used methodology and the data we used. In the fourth part we observed the share of individual factors in the production of the industry and services sectors. In the 5th part we summarized the achieved results.

\section{Literature Review and Research Background}

Research on economic growth and country productivity has been one of the most popular topics in economics for decades. Many researchers analysed empirically the patterns of economic growth in the world. A major wave of the literature was inspired by the seminal works of many authors - Abramovitz, Barro, $[1,2,3,4,5,17,18]$ The authors used different methods of analysis and quantification in their research. The growth accounting framework is one of the methods used. The pioneers of this method were [2] and [26]. Further adjustments brought [14, 15], or [19]. In these analyses we use a standard Cobb-Douglas production function approach (as in $[8,19$, $20,25])$. We mainly follow the explanation provided by $[12,13,15]$.

The aim of the article was to find out whether the economic growth is achieved in the same way in selected countries. At the same time, we want to find out whether the economic growth has been extensive or intensive. We selected two CEE countries (OECD term for 12 countries from Central and Eastern Europe). The Czech Republic and the Slovak Republic are countries of the former commonwealth - Czechoslovakia. Currently they are part of V4 countries. In 2004, they joined the EU and are also part of other groupings (OECD, NATO). Despite the common history, the economic development of the countries is not very similar. From the point of view of the unemployment rate, the average unemployment rate over the last 24 years was $6.5 \%$ (Czechia) and $14.2 \%$ (Slovakia) over the same period. Slovakia's inflation has an average of $4.6 \%$ over the last 24 years, in the Czech Republic it is $1 \%$ less.

Foreign direct investment is also one of the factors for future economic growth. As [10] mentioned the region of CEE is the fourth most attractive region in the world for investors. Authors [6] found that foreign investment has been an important factor in productivity growth of CEECs. There is a very visible impact of the crisis in this area. While in the pre-crisis era, Slovakia was a leader in the volume of FDI, after the crisis the situation changed. As [10] concluded, among the countries of the V4, the highest attractiveness for foreign investors is reported by the Czech Republic whose strength is the macroeconomic environment, and weakness is represented mainly by the bureaucratic delays. On the other hand, the least attractive country seems to be the Slovak Republic. [9] 
As we mentioned, current rapid development forces the country to find effective solutions. It therefore focuses on the productivity of the economy and, in particular, of its components. It does not just focus on the input itself. As [11] state, an important source of economic growth is, besides labor and capital, the aggregate productivity of these factors. Growth of aggregate factor productivity is the result of qualitative changes, also referred to as intense growth factors. A similar view in their work was presented by $[7,16,21]$, who expanded their exploration of another dimension in the form of human capital as another factor in the production of the economy. In this way they gained the dimension of the modern valuation of inputs into the production process.

In our research and testing, we have retained our original function, not spreading it about human capital. Our objective was to monitor the development of the share of factors from sector to sector.

\section{$3 \quad$ Methodology and Data}

\subsection{Methodology}

Suppose we use the basic form of the Cobb-Douglas production function. Aggregate output (Y) consists of consumption goods (C) and investment goods (I). These goods are produced from labour services (L) and capital (K). [19] Productivity is usually represented as a Hicks-neutral augmentation (A) of aggregate inputs:

$$
Y_{t}\left(C_{t}, I_{t}\right)=A_{t} F\left(L_{t} K_{t}\right)
$$

The first step is derivation of the equation. The next one in this derivation is to express the production function in growth rate form.

$$
\frac{\hat{Y}_{t}}{Y_{t}}=\frac{\partial Y}{\partial K} \frac{K_{t}}{Y_{t}} \frac{\hat{K}_{t}}{K_{t}}+\frac{\partial Y}{\partial L} \frac{L_{t}}{Y_{t}} \frac{\hat{L}_{t}}{L_{t}}+\frac{\hat{A}_{t}}{A_{t}}
$$

A "roof" over the variables is denoting time derivatives. The corresponding ratios are rates of change. This form of calculation means that the rate of output growth equals the growth rate of capital and labour weighted by their output elasticities plus the growth rate of the Hicksian shift parameter. These elasticities represent factor-income shares $s_{K_{t}} ; s_{L_{t}}$ when inputs are paid the value of their marginal products:

$$
\frac{\partial Y}{\partial K}=\frac{r}{p} ; \frac{\partial Y}{\partial L}=\frac{w}{p}
$$

Then:

$$
T F P=\frac{\hat{Y}_{t}}{Y_{t}}-s_{K_{t}} \frac{\hat{K}_{t}}{K_{t}}-s_{L_{t}} \frac{\hat{L}_{t}}{L_{t}}=\frac{\hat{A}_{t}}{A_{t}}
$$


TFP defines the „residual“ as the growth rate of output which is not explained by the share-weighted growth rates of the inputs. [15]

We want to examine the changes in the input prices so we use the dual approach provided by [13] or [12]. We start with:

$$
Y=r K+w L
$$

After the differentiation of (5) and dividing by $\mathrm{Y}$ we have

$$
\begin{aligned}
& \grave{Y}=\grave{r} K+r K^{\prime}+\grave{w} L+w \grave{L} \\
& \frac{Y}{Y}=\dot{r} \frac{K}{Y}+\frac{r}{Y} \dot{K}+\mathfrak{w} \frac{L}{Y}+\frac{w}{Y} \grave{L} \\
& \frac{Y}{Y}=r \frac{K}{Y}\left(\frac{r}{r}+\frac{K^{\prime}}{K}\right)+w \frac{L}{Y}\left(\frac{\dot{w}}{w}+\frac{\grave{L}}{L}\right)
\end{aligned}
$$

We use the substitution and it brings us:

$$
Y^{`}=s_{K}(\hat{r}+\hat{K})^{\prime}+s_{L}(\hat{w}+\hat{L})
$$

where the identities $s_{K}$ and $s_{L}$ represent the factor-income share and the sum of factorshares is equal to unit

$$
s_{K}+s_{L}=1
$$

Variables “ $\hat{r} ; \hat{w} ; \hat{K} ; \hat{L}$ ” represents growth rates. [12]

\subsection{Data}

All the necessary data for the calculation were available from one source: OECD. We used the data on an annual basis, sample period was from 2008 to 2016 . The data we used to monitor the sectors was used in accordance with ISIC rev. $4^{\text {th }}$

In particular, the real interest rate used to measure the rental price of capital is represented by the 3-month nominal interbank offered rate deflated by CPI inflation. The real wage is calculated as the ratio of the nominal wage rate to the consumer price index. The aggregate output is represented by GDP. The labour share was calculated as a ratio of total labour costs and gross value added. (Table 1)

Table 1. Capital and Labour Shares.

\begin{tabular}{crrrrrr}
\hline Country & \multicolumn{3}{c}{ Czechia } & \multicolumn{4}{c}{ Slovakia } \\
\hline Sector & Economy & Industry Services & \multicolumn{1}{c}{ Economy } & Industry Services \\
Labour share in \% (2008-2016) & 44.31 & 44.31 & 45.3 & 40.91 & 40.69 & 44.28 \\
Capital share in \% (2008-2016) & 55.69 & 55.69 & 54.7 & 59.09 & 59.31 & 57.72 \\
\hline
\end{tabular}


The values of both countries are comparable and similar. The Czech or Slovakian values are smaller than those of the United States (62\%), G20 (61\%), Japan (57\%).

\section{Development of individual factors and production in industry and services}

\subsection{Industry - Crisis and post-crisis period (2008-2016)}

In the crisis, the situation has changed mainly in the field of labour. In both countries, the number of hours worked decreased, but the labour share of economic growth increased significantly compared to the situation before the crisis. (Table 2)

Table 2. Industry - Average Changes and Shares 2008-2016.

\begin{tabular}{lccccc}
\hline & Czechia & Slovakia & Czechia & Slovakia \\
\hline average share on GDP & & & average change & & \\
Labour & 0.0764 & 0.0582 & Labour & $(-0.0039)$ & $(-0.0056)$ \\
Capital & 0.3406 & 0.2376 & Capital & 0.0053 & 0.0106 \\
TFP & 0.583 & 0.7042 & TFP & 0.0248 & 0.0320 \\
& & & Rental price of Capital & $(-0.1618)$ & $(-0.3583)$ \\
& & & Real Wage & 0.015 & 0.0179 \\
\hline
\end{tabular}

A significant change was brought about by the crisis in Slovakia, (Fig. 1) which started to benefit from reforms and investments already made, and the increase in production was mainly due to changes in the TFP. In Czechia, the situation has not changed significantly, but the share of capital has declined. (Table 2)

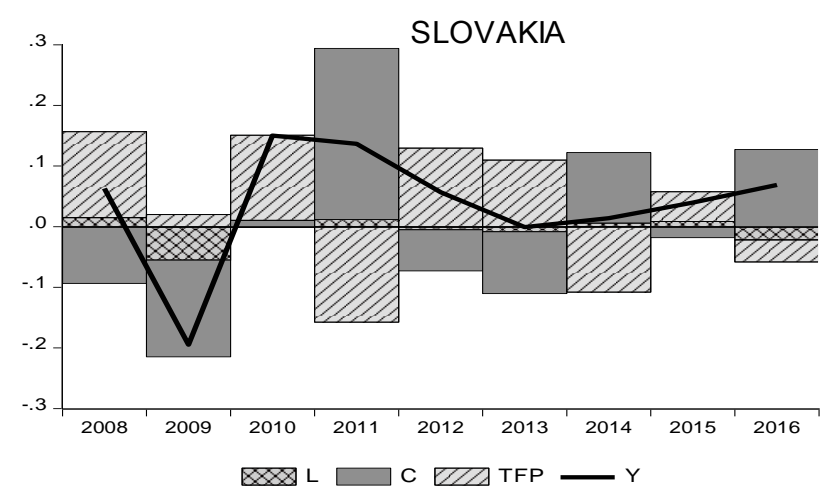




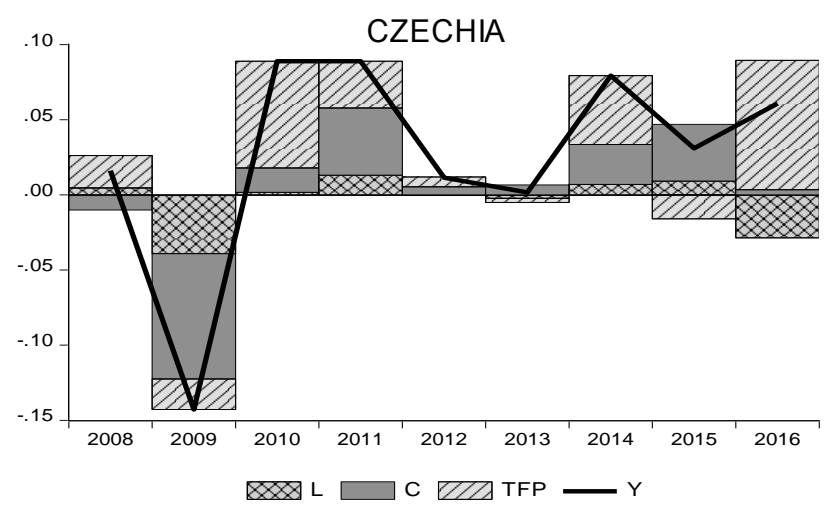

Fig. 1. Slovakia and Czechia - Industry - Input Shares on Output 2008-2016.

As stated in the OECD report [23], Slovakia has a rapidly growing economy and is expected to continue this trend for several years, but its industry is predominantly based on the automotive industry that is easily influenced by external factors. Besides, the population of Slovakia belongs to the fastest aging population among the OECD countries. Consistent with the fact that in Slovakia over the past few years almost 6\% of the population emigrated, at least half of whom were people with a minimum of secondary education, the problem is whether there will be enough qualified labour. And even with increasing automation in industry.

Industry has been boosted by a rebound in the automotive sector, which has benefited from both demands from abroad and domestic orders in Czechia. (Fig. 1) Exports grew solidly in 2015, helped by stronger demand from trading partners. As the OECD notes [22], after reforming the tax system, the Czech Republic must undertake further structural reforms (especially in the social sphere, the pension system, ...) and complete the restructuring of state-owned enterprises in order to be competitive.

As our results showed, our assumption of the same main factor was confirmed in the case of both countries. (Table 2) Here TFP was the main factor.

\subsection{Services - Crisis and post-crisis period (2008-2016)}

The crisis has also changed the service sector. The share of this sector has declined by $10 \%$ on total output in the Czech Republic and Slovakia.

Table 3. Services - Average Changes and Shares 2008-2016.

\begin{tabular}{lccccc}
\hline & Czechia & Slovakia & Czechia & Slovakia \\
\hline average share on GDP & & & average change & & \\
Labour & 0.096 & 0.046 & Labour & 0.0017 & 0.0039 \\
Capital & 0.335 & 0.6084 & Capital & 0.0090 & 0.0199 \\
TFP & 0.5691 & 0.3456 & TFP & 0.0188 & 0.0174 \\
& & & Rental price of Capital & $(-0.1544)$ & $(-0.3819)$ \\
& & & Real Wage & 0.0117 & 0.0177 \\
\hline
\end{tabular}


As stated in the OECD report [24], productivity (TFP) increases in the service sector.
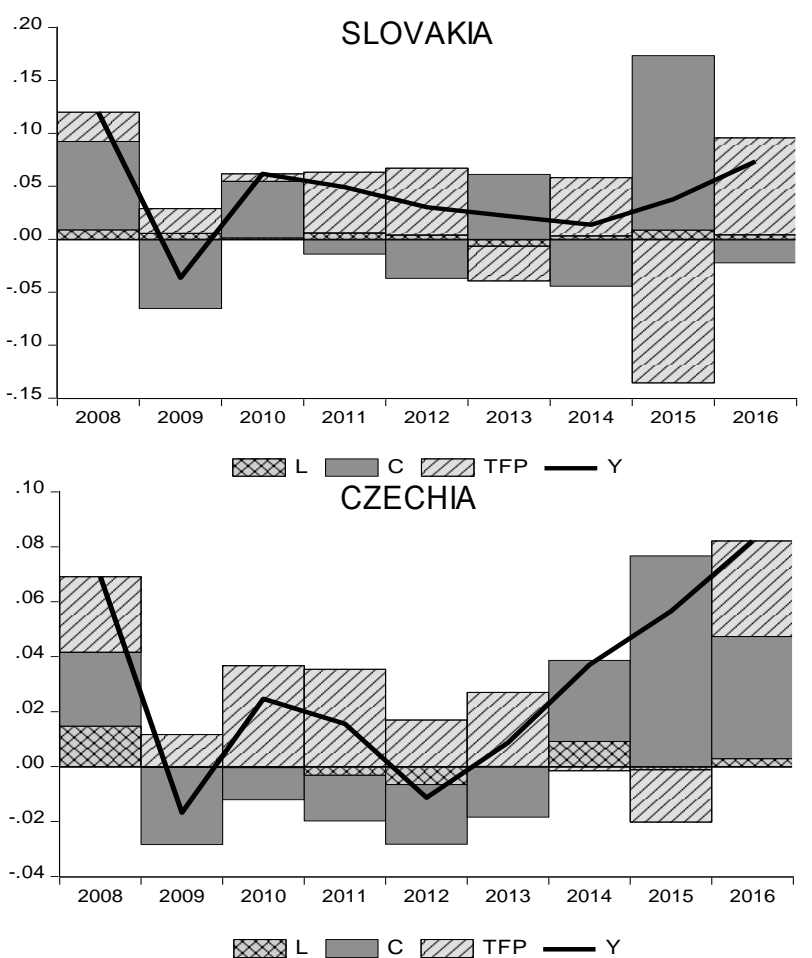

Fig. 2. Slovakia and Czechia - Services - Input Shares on Output, 2008-2016 (own calculations)

It is true that the average level of productivity is higher in manufacturing than in services, but modern services are rapidly catching up. From the perspective of our countries, the claim for an increase in the impact of the TFP is confirmed in the case of the Czech Republic. In the case of Slovakia, growth will continue to rise through the increase in capital. (Fig.2)

Our assumption has been met by one country. It is Czechia. The TFP is the main factor. (Table 3) Slovakia has had a development in the services sector mainly dependent on capital, but the whole economy relied on changes in the TFP.

\section{Conclusions}

The crisis has changed the share of individual inputs, contributing to the creation of economic growth in each country. A common feature of both countries is the relatively small share of labour on the growth of economic growth. The impact of labour is in fact negligible - both in terms of hours worked and in terms of wages. However, capital prices declined throughout the period. Prices have changed much 
faster than the volume of capital has changed. The development of the real capital did not reflect the development of market prices.

Our assumption of the same major factor for the whole economy as well as the sectors has been only partially fulfilled. There was complete agreement - the whole economy + both sectors - only in case of Czechia. There has never been a case that the main factor has been labour.

However, we cannot fully explain the reasons that led to such results. We believe that in order to better understand the overall situation of these economies and their economic growth, it is necessary to further analyse the concrete contribution of individual sectors to economic growth. We believe that the sectoral analysis can find the necessary answers and at the same time it is possible to estimate the effective adjustment of the internal structure of economies. This can lead to a more effective use of fiscal and monetary policy instruments as well as a better functioning of global value chains. Therefore, this will be the subject of our further research.

Acknowledgements. This paper was written in connection with scientific project VEGA no. no. 1/0961/16. Financial support from this Ministry of Education`s scheme is also gratefully acknowledged.

\section{References}

1. Abramovitz, M.: Catching Up, Forging Ahead, and Falling Behind. Journal of Economic History 46(2), 385-406 (1986).

2. Abramovitz, M.: Resource and Output Trends in the United States Since 1870. NBER Occasional Paper 52(May 1956), 1-23 (1956).

3. Barro, R.J.: Economic Growth in a Cross Section of Countries. Quarterly Journal of Economics, 106(2), 407-443 (1991).

4. Barro, R.J.: Human Capital and Growth. American Economic Review 91(2), 12-17. (2001), DOI: 10.1257/aer.91.2.12.

5. Baumol, W. J.: Productivity Growth, Convergence, and Welfare: What the Long-Run Data Show. The American Economic Review 76(5), 1072-1085 (1986).

6. Bijsterbosch, M., Kolasa, M.: FDI and Productivity Convergence in Central and Eastern Europe an Industry-Level Investigation. ECB Working Paper 992(January 2009), 1-43 (2009).

7. Bosworth, B., Collins, S. M.: The Empirics of Growth: An Update, Brookings Institutions, unpublished paper, https://www.brookings.edu/wp-content/uploads/2016/06/200303071.pdf. (2003)

8. Dimelis, S. P., Papaioannou, S. K.: Entry Regulation, Public Ownership and TFP Growth: Industry - Level Evidence from South European Countries. The Manchester School 84(6), 749-770 (2016), DOI: 10. 1111/manc.12131.

9. Ernst \& Young Global Limited. EY's European attractiveness survey 2015 - Comeback time. http://www.ey.com/Publication/vwLUAssets/EY-european-attractiveness-survey2015/\$FILE/EY-european-attractiveness-survey-2015.pdf, last accessed 2017/09/26

10. Gontkovičová, B., Tkáčová, A., Kralik, A.: Assessment of FDI Attractiveness of V4 Countries. Journal of Interdisciplinarity in Theory and Practice 10(September 2016), 5460 (2016). 
11. Hájek, M., Mihola, J.: Analýza vlivu souhrnné produktivity faktorů na ekonomický růst České Republiky. Politická ekonomie, 57(6), 740-753 (2009), DOI: 10.18267/j.polek.707.

12. Hloušek, M.: Growth Accounting for Visegrad States: Dual Approach. Research Centre for Competitiveness of Czech Economy. Working Paper 17, 1-22 (2007).

13. Hsieh, C. T.: What Explains the Industrial Revolution in East Asia? Evidence from the Factor Markets. American Economic Review 92(3), 502-526 (2002).

14. Hulten C.R.: The measurement of capital. In: Berndt E.R., Triplett J.E. (eds). Proceddings of the Conference on Research in Income and Wealth. 50 th Anniversary Conference. 1988, vol. 54, pp. 119-158. University of Chicago Press, Chicago (1990).

15. Hulten, C.R.: Growth Accounting. Handbook of the Economics of Innovation. NBER Working Paper 15341(September 2009), 1-78 (2009).

16. Jongen, E.L.W.: An analysis of past and future GDP growth in Slovenia. Institute for Economic Research. Working Paper 25(December 2004), 1-43 (2004).

17. Krugman, P.: The Myth of Asia's Miracle. Foreign Affairs 73(6), 62-78 (1994).

18. Mankiw, N.G., Romer, D., Weil, D.N.: A contribution to the empirics of economic growth. The Quarterly Journal of Economics 107(2), 407-437 (1992), DOI: 10.2307/2118477.

19. Musso, P.: Capital Obsolescence, Growth Accounting and Total Factor Productivity. Revue de l'OFCE 5(97), 217-233 (2006), DOI: 10.3917/reof.073.0217.

20. Novak, M.: Analysis of the Nature of Economic Growth of Slovenian Economy. Managing Global Transitions 1(2), 153-167 (2003).

21. Novak, M., Bojnec, S.: Human Capital and Economic Growth by Municipalities in Slovenia. Managing Global Transitions 3(2), 157-178 (2005).

22. OECD: OECD Economic Surveys: Czech Republic. https://www.oecd.org/eco/surveys/Czech-Republic-2016-overview.pdf, last accessed 2017/09/26

23. OECD: OECD Economic Surveys: Slovak Republic. http://www.keepeek.com/DigitalAsset-Management/oecd/economics/oecd-economic-surveys-slovak-republic2017_eco_surveys-svk-2017-en\#.WbRb_dJJYdU\#page12, last accessed 2017/09/26

24. OECD: Services Trade Policies and the Global Economy, http://www.oecd.org/publications/services-trade-policies-and-the-global-economy9789264275232-en.htm, last accessed 2017/09/26

25. Podpiera J., Raei, F. and Stepanyan, A.: A Fresh Look at Potential Output in Central, Eastern, and Southeastern European Countries. IMF Working Paper, No. 37/2017. (2017)

26. Solow, R.M.: Technical Change and the Aggregate Production Function. The Review of Economics and Statistics 39(3), 312-320 (1957). 